
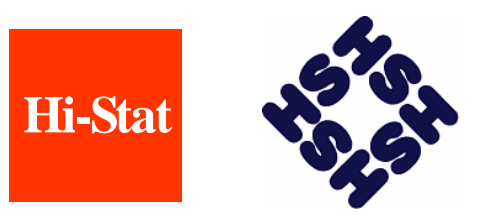

Discussion Paper Series

No.53

\title{
Failure of the WTO Ministerial Conference at Cancun:
}

Reasons and Remedies

Robert E. Baldwin

December 2004

Hitotsubashi University Research Unit for Statistical Analysis in Social Sciences A 21st-Century COE Program

Institute of Economic Research Hitotsubashi University Kunitachi, Tokyo, 186-8603 Japan http://hi-stat.ier.hit-u.ac.jp/ 
Failure of the WTO Ministerial Conference at Cancun:

Reasons and Remedies

Robert E. Baldwin ${ }^{1}$

\section{INTRODUCTION}

The collapse of the September 2003 Ministerial Conference held by the World Trade Organization (WTO) in Cancun, Mexico raises new concerns about the organization's ability to serve as the forum for continued multilateral liberalization of world trade. This failure means that two of the five ministerial meetings held since the WTO replaced the General Agreement on Tariffs and Trade (GATT) in 1995 have not been successful despite extensive negotiations among members prior to the formal meetings. The breakdown of the effort to launch a new round of multilateral negotiations at the December 1999 WTO meetings in Seattle represents the greater setback for the world trading system, but the failure at Cancun to move the stalled negotiations on the Doha Round forward was a very disturbing indication of the fragility of the existing institutional arrangements for settling trade disputes among nations and promoting the further expansion of world trade. Moreover, the efforts during the fall of 2003 and spring of 2004 to resume meaningful negotiations proved discouraging. But there was some progress made finally in July 2004 to lessen these concerns and a framework for future negotiations as had been agreed upon.

The frustrations of the WTO ministerial meetings suggests an outcome that appears increasing likely - indeed we already see considerable evidence of its emergence - which is, in effect, the replacement of the multilateral trading system by a complex set of regional and bilateral trading agreements among nations. The WTO may still survive as an institution to assist

\footnotetext{
${ }^{1}$ ROBERT E. BALDWIN is from the University of Wisconsin - Madison. Helpful comments have been provided by Ippei Yamazawa and participants in the March 2004 pre-conference meeting of authors in Ann Arbor and the May 2004 conference in Tokyo.
} 
in settling trade disputes among nations and facilitate negotiations on some trade matters, but there is also a danger that the organization could collapse. For example, some major industrial trading powers or groups of developing countries may simply announce their refusal to accept certain rulings of the Appellate Dispute Settlement Body established under the WTO or to carry out liberalization measures already agreed on but later judged not to be in their interests. Such actions are likely to produce retaliatory responses that effectively destroy the WTO and promote instability in the world trading system.

This paper first discusses four general developments in the world trading system that have made it increasingly difficult in recent years for nations to reach multilateral agreements aimed at further liberalizing international trade, namely, (1) the increased technical complexity and disruptive domestic economic effects of the issues being negotiated; (2) the shift in relative bargaining power among the negotiating participants in favor of the developing countries; (3) the proliferation of bilateral and regional free trade agreements (FTAs) in contrast to multilateral agreements, and (4) the increased emphasis on achieving "fairness" rather than reciprocity in trade liberalization. Differences in negotiating positions of the participants on the major specific negotiating subjects of the Doha Round, such as new rules covering investment, competition policy, government procurement policy, and trade facilitation (the so-called Singapore issues), agricultural liberalization, changes in antidumping and countervailing duty rules, the tariff-cutting rule to increase access to nonagricultural markets, and further liberalization in the services sector, are then considered as well as the likelihood of reaching compromises on these matters. Finally, the possibilities of reaching acceptable balances of concessions and gains are considered for such key participants as the Group of 20 developing countries, the European Union (EU), the United States, and other industrial countries. 


\section{THE INCREASED DIFFICULTIES OF LIBERALIZING TRADE ON A MULTILATERAL BASIS}

a. Increased Issue Complexity, More Extensive Domestic Adjustment Effects, and Hard-Core Protectionism

A prime historical example of an overly complex negotiating agenda contributing to the failure to successfully conclude trade negotiations was the effort to establish the International Trade Organization (ITO) at the end of World War II. In 1948 representatives from over 50 countries signed the Havana Charter for an ITO establishing a very comprehensive set of rules and procedures for the purpose of promoting the expansion of employment and the production, exchange and consumption of goods. It was to be submitted for approval to the governments of the signatories. However, when it became clear that it was highly unlikely that the U.S. Congress would give such approval, the Truman Administration quietly dropped its ratification efforts. Other governments followed suit.

That the proposed ITO covered a wide range of complex issues, some of which were only indirectly related to international trade and not covered in previous trade agreements, clearly contributed to the problem of securing ratification by the diverse governments and economies represented among the signatories. For example, the Charter included detailed rules covering restrictive business practices and intergovernmental commodity agreements as well as pledges by governments to maintain full employment, promote foreign investment, and eliminate unfair labor practices. However, to gain agreement among the diverse set of negotiating countries on such a complex set of issues, it became necessary to make so many exceptions to the application of free market principles that most U.S. business groups who had previously supported tariffreducing negotiations under the Reciprocal Trade Agreements program opposed the final document. These groups feared that the ITO would not open up foreign markets for their exports and would promote the kind of government intervention into economic affairs that they opposed. This opposition coupled with the usual highly negative reaction from protectionist groups and only lukewarm support from academic economists and other traditional supporters of liberal trade 
policies doomed the ratification of the ITO in the United States. ${ }^{2}$ The final outcome was that only the commercial-policy sections of the Charter establishing rules covering such traditional marketaccess matters as tariffs, quantitative restrictions, subsidies, dumping and state trading were implemented in 1948 by 23 countries as the General Agreement on Tariffs and Trade (GATT), and then only by executive action in the United States. However, the GATT included the key provision that countries participating in multilateral rounds of tariff-reducing negotiation extend these reductions to all countries, whether they participated in the negotiations or not.

The early rounds of multilateral negotiations conducted under the GATT were comparatively simple. They covered only reductions in tariffs and quantitative import restrictions, and the number of countries participating in the first five negotiating rounds through 1961 averaged 25 in contrast to the 148 countries engaged in the Doha Round negotiations. After consulting with various domestic interest groups, member governments would first draw up a list of individual traded goods on which they would be willing to reduce tariffs to particular levels (their offer lists) and a list of goods on which they would request tariff reductions of particular amounts from foreign countries (their request lists). Each country would then enter into a series of simultaneous bilateral negotiations in which its offer of a tariff concession on a particular product was made to the country that was the principal supplier of the product. Each country would also provide this negotiating partner its list of requested tariff reductions from that country. The objective of the item-by-item negotiations was to achieve overall balance or reciprocity among countries in the tariff concessions made and received. The negotiating process usually took several months and often involved both requests by negotiators from their governments for authority to offer deeper cuts on particular tariff items and withdrawals or reductions in offers to particular countries in order to achieve an acceptable balance.

\footnotetext{
${ }^{2}$ For a detailed analysis of the efforts to ratify the ITO, see Diebold (1952).
} 
A number of other factors besides the relative simplicity of the negotiating process facilitated the early tariff-reducing negotiations under the GATT. Average tariff rates were still high as a consequence of the protectionist actions taken by most governments during the 1930s world-wide economic depression. For example, U.S. tariff rates on dutiable imports averaged 30 percent in 1945 with many individual rates much higher. Consequently, there was considerable "water" in levels of protection for many sectors in the sense that they could be cut with only minimal domestic adjustment pressures. Many members also took advantage of provisions in the GATT permitting the imposition of quantitative import control on balance-of-payments grounds. Moreover, the highly sensitive sector of agriculture became effectively exempt from GATT rules as a consequence of a GATT waiver secured by the United States in 1955.

Although the early GATT negotiating rounds were completed relatively easily compared to recent multilateral negotiations, it became increasingly apparent that the item-byitem approach with the exchange of offer and request lists was severely limited in its ability to bring about continuing rounds of significant average duty reductions. Whereas the first round in 1947 produceed an average cut in all duties of 21.1 percent, the next four rounds resulted in only an average cut of 2.7 percent. Consequently, with the urging of the United States, member countries agreed in 1964 to launch a tariff-cutting round (the Kennedy Round, 1964-67) aimed at reducing tariffs by 50 percent "with a bare minimum of exceptions which shall be subject to confrontation and justification.”3 At the insistence of the European Economic Community (EEC), which pressed for a formula that would cut higher duties a greater percentage than lower duties, it was also agreed that: "In those cases where there are significant disparities in tariff levels, the tariff reductions will be based on special rules of general and automatic application.” Participants

\footnotetext{
${ }^{3}$ This quotation and the others in the rest of the paragraph are part of the resolutions adopted at the ministerial meeting of the General Agreement on Tariffs and Trade on May 23, 1963. They were published in the Department of State, Bulletin, June 24, 1958 and are also reproduced as appendices in Preeg (1970).
} 
pledged to make every effort to reduce barriers to exports of the less developed countries, "but the developed countries cannot expect to receive reciprocity from the less developed countries.” They also agreed to "deal not only with tariffs but also with non-tariff barriers."

Hope that the tariff-reducing part of the negotiations could be concluded fairly quickly so that members could begin to negotiate on nontariff trade barriers (NTBs) proved much too optimistic, and the negotiations became bogged down over the disparities issue. The negotiators faced some fairly complex issues concerning the formula for measuring disparities, the countries against whom the disparities would be measured, and the minimization of unintended adverse effects against third countries. But the stalemate reached over the disparities issue seemed more related to the basic difficulty of the United States and the European Economic Community (EEC) accommodating to the new economic power of the Community than to reaching agreement on these technical issues. ${ }^{4}$ Fortunately, in the end only the EEC invoked a disparities rule and then only on a relatively small number of items. Not unexpectedly, the negotiations over agricultural products also were difficult and time-consuming, mainly because of the trade-distorting features of the EEC's common agricultural policy. The time-consuming nature of the negotiations over these and other tariff-related issues did not leave much time for negotiations dealing with nontariff trade measures and little was accomplished in this area. ${ }^{5}$

In the Tokyo Round (1973-79) ${ }^{6}$ and the Uruguay Round (1986-92) ${ }^{7}$, however, negotiations on nontariff trade issues played a central role, and their complexity played an important part in determining the length of these two negotiations. In the Tokyo Round, for example, six codes dealing with nontariff barriers were adopted that covered subsidies, technical

\footnotetext{
${ }^{4}$ For detailed discussion of the disparities issue, see Baldwin (1965) and Preeg (1970).

${ }^{5}$ For an analysis of the entire Kennedy Round negotiations, see Preeg (1970).

${ }^{6}$ See Winham (1986) for an analysis of the Tokyo Round negotiations.

${ }^{7}$ Preeg (1995) presents a comprehensive analysis of the Uruguay Round.
} 
barriers to trade, import licenses, government procurement, customs valuation, and antidumping procedures. Agreements reached in the Uruguay Round added nontariff rules dealing with such topics as trade-related investment measures, safeguards against injurious increases in imports, intellectual property rights, trade in agricultural products, trade in services, and trade in textiles and clothing, Furthermore, agreements were negotiated that further strengthened the rules set forth in most of the Tokyo Round codes.

One obvious problem that arises with establishing nontariff rules is the difficulty of assessing reciprocity in the agreements signed, since there usually is no simple yardstick for comparison like the depth and coverage of tariff reductions made and received. Another is that domestic interest groups not directly involved in international trade may be adversely affected by the nontariff agreements yet may not have been consulted in the negotiation of the agreements. For example, the government procurement code initially agreed to in the Tokyo Round by U.S. negotiators threatened the government's social program of facilitating the growth of small minority businesses in the United States by abolishing the preferential treatment they received in bidding on government contracts. Similarly, permitting unrestricted foreign direct investments (FDI) in a country can undermine domestic programs aimed at preserving certain environmental conditions or at providing special economic treatment for certain social groups. For informed decision-making that will not be regretted after the decisions have been reached, the complex technical features of some nontariff agreements also require levels of expertise that trade-policy agencies in many small or less developed countries do not possess. Negotiations on such issues as intellectual property rights, antidumping and countervailing duty rules, trade in services and FDI have amply demonstrated this point.

The complexity of nontariff negotiations and their unanticipated domestic effects was much less consequential in the Tokyo Round than the Uruguay Round because signing on to the codes was optional in the Tokyo Round. Most developing countries opted not to commit themselves to the rules set forth in the codes and none of them was ever adopted by a majority of 
GATT members. Membership in the WTO, in contrast, required accepting all of the Uruguay Round agreements except the one covering government procurement policy. However, somewhat surprisingly, acceptance of the nontariff agreements by the developing countries did not prove to be too difficult, apparently because of the belief that the concessions by the developed countries in such areas as agriculture and textiles/apparel and the special and differential treatment granted the developing countries with regard to the nontariff rules convinced these countries that they were receiving a balanced package of concessions. The new, more-binding procedures adopted for settling trade-policy disputes also played an important role in generating support among the developing countries for the various Uruguay Round agreements. It was only after the various agreements were implemented that most developing countries reached the conclusions that they had not gained a satisfactory balance of concessions from the Uruguay Round.

\section{b. Shifts in Relative Economic and Political Power among WTO Members}

As in most foreign policy negotiations, the distribution of economic and political power among the participants together with their economic and political goals play an important role not only in shaping the agenda of trade negotiations but in determining how readily agreements are reached. From the late 1940s through the 1960s, for example, the United States used its economic, political and military dominance outside of the Soviet bloc to significantly shape the nature of the trade negotiations.

In this period, few developing or other developed countries were economically able to provide meaningful reciprocity by opening their markets to the extent the United States was prepared to do. They were still struggling to regain their pre-World War II economic status and unwilling to incur the additional short-run adjustment costs that meaningful trade liberalization brings. In contrast, the United States was greatly concerned about the expansion of Soviet political influence and, as a means of strengthening and gaining political support from other 
developed and less developed countries, was willing to reduce its own tariffs and provide massive foreign aid without insisting on immediate reciprocity. The other countries utilized GATT rules permitting import quotas and exchange controls on balance-of-payments or development grounds to insulate their domestic economies from any appreciable foreign competition.

The developing countries also were beginning to organize for the purpose of bringing political pressure on the developed countries to grant them special treatment in trade negotiations. They were instrumental, for example, in convening the United Nations Conference on Trade and Development in 1963 which urged the developed countries to grant preferential tariff treatment on imports of manufactured goods from developing countries. Similarly, near the end of this period, the EU countries (six at that time) and Japan began to exercise their new political power. The difficulty of quickly resolving the disparities issue in the Kennedy Round and the inability to reduce protection in agriculture significantly are examples of the effects of this new power alignment.

But it was not until the Tokyo Round of trade negotiation (1973-79) that the United States found that it could no longer call the shots in GATT trade negotiations. The EU, in particular, gained more and more economic and political power as it enlarged and recovered its economic vitality, and it became very much involved in the nature of the negotiations. In a sense, the story of the Tokyo Round is one of the United States and the EU trying to learn to adjust to the new power situation existing between them. Japan also exerted its increased economic and political power to shape negotiating outcomes to a greater extent than in the Kennedy Round, particularly in agriculture. Moreover, the developing countries were able to obtain "special and differential treatment" for themselves as an essential part of all trade agreements and to opt out of the codes negotiated on nontariff issues.

The dispute over agricultural policies between the EU and the United States and other agricultural exporting nations grew even more intense in the Uruguay Round (1986-92) as the EU expanded its export subsidization program. Because of the disagreement over the agricultural 
issue, the Round failed to conclude as scheduled at the December 1990 Ministerial Meeting in Brussels. Agricultural negotiations shut down until November 1992 when the so-called US-EU Blair House Accord was reached in Washington. Negotiations on the other issues continued, however, with a rather surprising willingness to compromise on important issues by the major trading powers and the developing countries. But final agreements covering agriculture and the other issues were not concluded until December 1993.

The ongoing Doha Round negotiations (2001- ) have revealed an important new power shift among WTO members that has significantly increased the difficulty of reaching agreements on the ambitious agenda. The negotiations at Cancun collapsed after a group of 20 developing countries led by Brazil, China and India (and including such other important WTO members as Mexico, South Africa and Thailand) refused to negotiate on the so-called Singapore issues (competition, foreign investment, government procurement and trade facilitation) in the absence of greater commitments by the developed countries to reduce agricultural subsidies and lower import barriers on agricultural products. The developing countries had been vigorously pressing for greater concessions from the developed countries at least since the Kennedy Round, but it was not until the Cancun meeting that they were prepared to break up a negotiation at the Ministerial level on the grounds that they were not receiving a balanced package of concessions..

There had been many manifestations of the dissatisfaction of the developing countries with the existing balance of trading concessions since shortly after the Uruguay Round. For example, these countries had resisted holding the Ministerial Meeting in Qatar that launched the Doha Round because of the lack of significant progress on the so-called implementation-related issues dealing with the difficulties they were having with some of the WTO agreements reached in the Uruguay Round. Moreover, at the meetings in Doha, they had insisted on inserting into the Ministerial Declaration the statement that negotiation on the Singapore issues would take place at the next Ministerial Meeting "on the basis of a decision to be taken, by explicit consensus, at that Session on modalities of negotiation.” (Draft Ministerial Declaration, November 14, 2001). They 
had also long complained about the slow progress of reform in the agricultural sector and in removing quantitative restrictions on imports of textiles and apparel into the developed countries.

The developed countries were clearly aware of the negotiating goals of the developing countries but seemed to believe that if the major developed-country trading powers presented a united position at Doha, the developing countries by themselves would not willing to accept the blame for a failed negotiation. Thus, less than a month before the Doha meetings, the United States and EU jointly presented a broad framework for improving market access for agricultural products and joined with Canada in presenting a proposal aimed at reaching an agreement on negotiating modalities for nonagricultural products. These and most other developed countries were clearly surprised when the key developing countries made good on their threat to walk away from the negotiations unless clear actions were taken early in the meetings towards meeting their objections to the existing trading system.

Unfortunately, adjusting to the reality of a new shift in the structure of influence in any negotiating group is difficult and time-consuming, as was found when the EU began to contest the dominance of the United States in GATT negotiations. In the aftermath of the collapse of the Cancun meetings, the United States apparently backed away from its August 2003 agreement with the EU that it was not necessary in the negotiations to fix a date for the complete elimination of export subsidies for agricultural products. In addition, some developing countries withdrew from the Group of 20, and it appeared for some time that there were difficulties in obtaining agreement among the remaining members on just what specific steps they should take.

\section{c. The Proliferation of Bilateral and Regional Trade Agreements}

Perhaps the most significant change in the trading system in response to the shifting power structure among trading nations since the formation of the GATT in 1948 has been the increase in the number of bilateral and regional FTAs among countries. To a growing extent, governments have utilized the provisions of the GATT and WTO permitting such agreements as a means of 
shaping trade polices more to their liking than those emerging from a multilateral WTO negotiating process. For example, the formation of the European Community in 1958 and its subsequent development was partly a response to the dominance of the United States in shaping the nature of the world trading system. Moreover, as U.S. trade negotiators have explicitly stated, the shift in U.S. trade policy from supporting only multilateral WTO efforts to liberalize trade to signing such bilateral trade agreements as those with Jordan (the first with a developing country to contain labor and environmental standards), Chile, Singapore, Australia, Morocco, and Central America and regional agreements such as the North American Free Trade Agreement (NAFTA) has been to a considerable extent due to the frustrations of U.S. negotiators in dealing with the increasing negotiating power of the EU, Japan and coalitions of developing countries, such as the Group of 20. Similarly, the Southern Common Market (Mercusor) formed by Brazil, Argentina, Uruguay and Paraguay (with Bolivia and Chile as associate members) and the formation of the Association of Southeast Asian Nations (ASEAN) are examples of developing countries attempting to counter the trade-bargaining power of the developed countries.

The rapid growth in the number of bilateral and regional agreements in recent years has been a major factor in accounting for the increased difficulties in negotiating multilateral agreements. Now both the developed and developing countries are quite prepared to expand their trading opportunities through these types of discriminatory agreements as an alternative to negotiating multilateral agreements. The WTO had been informed of the existence of 250 such agreements by the end of 2002, of which 130 were notified since 1995.

\section{d. The Increased Emphasis on "Fair Trade"}

The notion that countries should refrain from "unfair" trading practices has always been an integral part of GATT/WTO rules. An example is the provision permitting countries to ban products of prison labor. Clearly, the idea behind Article XX is that workers in an economic system where there is the right to choose among alternative employment and wage opportunities 
should not have to compete against workers who must work or face forced physical deprivation. Other unfair trade practices in the GATT/WTO are conditional on causing certain economic effects in the foreign country, however. Dumping, i.e., selling a product abroad at a price less than charged at home or selling the product below its costs of production, is condemned (and can be offset by an antidumping duty) only if it "causes or threaten to cause material injury to an established industry ... or materially retards the establishment of a domestic industry" (Article VI). Similarly, governments can impose countervailing duties if foreign governments provide subsidies to specific industries or enterprises duties if they cause or threaten to cause material injury to domestic producers. Export subsidies are banned outright except in the agricultural sector.

Efforts to broaden the list of actions considered to be unfair have been an important part of the history of GATT/WTO trade negotiations. The most significant of these efforts relates to introducing provisions calling for preferential treatment toward the developing countries on the part of the developed nations and implying that not doing so is "unfair". For example, the 1955 GATT amendment calling for regular multilateral negotiations among members directed to the substantial reduction of tariff and nontariff barriers to trade "on a reciprocal and mutually advantageous basis" included the statement that the negotiations should afford adequate opportunity to take into account "the needs of less-developed countries for a more flexible use of tariff protection to assist their economic development ...” At the outset of the Kennedy Round negotiations in the 1960s, it was agreed that the developed countries "cannot expect to receive reciprocity from less-developed countries.” This was followed in 1971 by an agreement among members to waive the nondiscrimination principle of Article I for ten years "to permit developed countries to accord preferential tariff treatment to products originating in developing countries and territories." The so-called "Enabling Clause” of 1979 extended this waiver indefinitely and generalized it to cover nontariff measures as well as regional agreements among developing countries. 
Ministerial declarations in both the Uruguay and Doha Rounds continued to urge the developed countries to grant "special and differential” preferential treatment to developing countries, especially the least developed among this group. Every formal agreement reached in the Uruguay Round includes an article calling upon developed countries to be less strict in the enforcement of GATT/WTO rules against developing countries or granting developing countries extra time to conform to these rules. The Doha Ministerial Declaration states that WTO members agree to review all special and differential treatment provisions "with a view to strengthening them and making them or precise, effective and operational." One of the reasons that the developing countries refused to continue negotiating at Cancun was the failure in their view of sufficient progress in meeting the provisions of set forth in their document on ImplementationRelated Issues and Concerns.

The developed countries have also relied increasing upon arguments of "fairness" in pressing their negotiating agenda. Even pro-trade politicians no longer argue for freer trade without also emphasizing the need for "fair trade" and a "level playing field." For example, various changes in U.S. unfair trade laws and administrative practices in the 1970s and 1980s resulted in a significant increase in the number of affirmative findings of dumping and foreigngovernment subsidization that has continued to the present time. There has also been a sharp increase in recent years in the number of charges of unfair trade behavior on the part of developing countries on grounds that their environmental and labor standards are too lax or not enforced. Thus far, new rules on these matters have not been introduced into the multilateral negotiating process, but the developed countries have been successful in including such rules in various bilateral and regional trade agreements with developing countries.

"Fair trade" considerations have little effect on the negotiating process when there is general agreement among WTO members that a particular trade-related activity is unfair, such as using prison labor to produce export goods. However, serious negotiating problems tend to arise when there is no such agreement. This is currently the case with respect to the effort by some 
developed countries to include in an enforceable manner the core labor standards of the International Labor Organization (ILO) as part of the fair trading rules of the WTO. These cover: (1) the freedom of association and the right to collective bargaining; (2) the abolition of child labor and elimination of forced labor; and (3) the elimination of discrimination in the workplace. The developing countries strongly oppose including these standards in the WTO on the grounds that they will be used by some developed countries in an effort to block imports of manufactured goods in which the developing countries have a comparative advantage due to their relatively abundant supplies of unskilled labor and thus their relatively low-wages. The developing countries have been successful thus far in excluding the subject of core labor standards from the agenda of WTO multilateral negotiating rounds. However, the United States has been able to include in its bilateral FTAs, commitments by both countries to enforce their own labor laws and strive to ensure that ILO labor standards are recognized and protected in domestic law. But it is evident that the disagreement between the developing and developed countries on what are "fair" trading practices is a major factor in making it more difficult to hold comprehensive and successful multilateral trade negotiation.

\section{DOHA ROUND PROSPECTS}

\section{a. Overall Outlook}

In view of the factors considered in the preceding section, it will be difficult to achieve the broad goals set forth in the Ministerial Declaration inaugurating the Doha Round. It is conceivable that the negotiations could collapse or, more likely, continue in name but not substance. One reason already discussed is simply the increased technical complexity of the matters under negotiation. But, in my view, the main cause for concern about the Round's success is the difficulty that WTO members face in accommodating to the new shift in negotiating power toward the developing countries that was confirmed at the Cancun ministerial meeting. The developing countries have long maintained that the agreements reached in GATT/WTO multilateral negotiations did not 
give sufficient weight to their negotiating position, which essentially has been that they should not be required to liberalize very much and only over an extended period. It was not until Cancun, however, that these countries were able to maintain a united position and demonstrate their negotiating strength by bringing about the collapse of the ministerial meeting. The history of the earlier challenge by the EU of U.S. dominance of the multilateral negotiating agenda suggests that it can take years rather than months for significantly changed bargaining-power relationships to stabilize so that negotiating equilibria with substantial trade liberalization are possible. .

Additionally, as previously discussed, successful negotiations are becoming more difficult to conclude due to the greater insistence on the part of the developed and developing countries on achieving "fairness" in the negotiating outcomes (in contrast to some objective measure of reciprocity) coupled with the growing divergence between the two groups in what they each considers to be a "fair" agreement. These difficulties of adapting to significant shifts in bargaining power among WTO members and of reconciling widely divergent views about "fairness" have led to the increasing use of bilateral and regional approach to liberalization in contrast to multilateral liberalization. The preoccupation of the EU with the addition of ten new members further compounds the problem of achieving progress on the Doha negotiating agenda. In view of these various considerations, it seems prudent to set the goals for the Doha Round considerably lower than those established in the 2001 Ministerial Declaration.

The November 2004 national election in the United States in which the country's general trade policies may prove to be a major issue, and the preoccupation of the EU with the addition of ten new members compounds the problem of achieving progress on the Doha negotiating agenda. Furthermore, if the Democrats win control of the White House and the Congress, there may be a complicating shift in the bargaining position of the United States towards a more protectionist stance. In view of these various considerations, it seems prudent to set the goals for the Doha Round considerably lower than those established in the 2001 Ministerial Declaration. 


\section{b. Singapore Issues}

There has already been general acceptance of allowing a decision whether to launch negotiations on the Singapore issues (investment, competition policy, trade facilitation, and transparency in government procurement) to be made separately for each issue according to its merits. Moreover, the chair of the Cancun meetings, Mexican Foreign Minister Luis Ernesto Derbez, had proposed in his final draft of a Ministerial Declaration for the meeting that negotiations on investment and competition policy be postponed for a later round. The EU, which had lobbied hard for negotiating on all four issues simultaneously, has accepted this proposal. A number of developing countries argue that negotiations on these issues should be restricted only to trade facilitation in this round.

One possible compromise on this matter would be to negotiate only on trade facilitation in this round and set up Working Groups on the other Singapore issues that would, for example, investigate what should be considered trade-related anti-competitive practices in the developed and developing countries, the adjustment problems that would be faced if various competition rules were enforced, the costs of such enforcement, possible means of funding enforcement mechanisms, and so forth. Currently very little is known about these subjects, particularly in the developing countries. It would be made clear that the studies would not imply any commitment to negotiate on these issues in future rounds.

\section{c. Agriculture}

The outcome of the agricultural negotiation is likely to be the key issue determining whether the Doha Round will succeed even with such a scaled back agenda, however. In this regard, it is useful to recall the key sentence in the 2001 Ministerial Declaration on agriculture that was agreed on only after much negotiation. It is: "Building on the work carried out to date and without prejudging the outcome of the negotiations we commit ourselves to comprehensive negotiations aimed at: substantial improvements in market access; reductions of, with a view to 
phasing out, all forms of export subsidies; and substantial reductions in trade-distorting domestic support." The phrase "with a view to phasing out" had been in brackets until the final draft (meaning that there was still not consensus on including it) and was removed only when the phrase "without prejudging the outcome of the negotiations" was inserted.

The developing countries as well as the United States and other developed-country exporters of agricultural products interpreted the first phrase as an agreement to fix a future date by which all export subsidies would be phased out, whereas the EU considered the phrase about not prejudging the outcome of the negotiation as meaning that there is no firm agreement to phase out export subsidies by a certain date. The final draft of a Ministerial Declaration by the chair of the Cancun meetings, Mexico’s Foreign Minister Luis Ernesto Derbez, proposed a compromise in which export subsidies on products of particular interest to developing countries would be eliminated over a fixed time period and other export subsidies would be reduced with a view to phasing them out but members would not establish a fixed date for eliminating all agricultural export subsidies. The Cancun meeting broke down before this proposal was fully debated, but the General Council Chair, Carlos Perez De Castillo, who led the effort to restart the negotiations after the Cancun failure has argued that there seems to be considerable support for using the Derbrez text as the starting point for further agricultural negotiation. However, the EU has expressed some hesitancy on this point. Moreover, such countries as India and Australia have openly opposed beginning future negotiations with this text. Thus, prospect for the agricultural negotiations are still very much uncertain, although a possible basis for an acceptable compromise appears to have been reached in July 2004.

\section{d. Implementation Issues}

As noted on the WTO website, "no area of WTO work received more attention or generated more controversy in the two years before the Fourth Ministerial Conference in Doha, Qatar, than the issue of developing countries' problems in implementing the WTO Agreements.” Several of the 
implementation concerns of the developing countries were settled before the Cancun meetings but most were allocated to various groups for negotiation at the ministerial meetings. Given the importance of these issues for the developing countries, it would seem more appropriate if serious negotiations are resumed to assign this entire topic to a separate negotiating group. Otherwise, the individual issues are not likely to receive the attention they deserve collectively.

\section{e. Antidumping and Countervailing-Duties}

Negotiations aimed at "clarifying and improving disciplines" under the existing antidumping and countervailing-duty agreements of the WTO are another area where reaching agreement among members will be very difficult. This topic was put on the Doha Round agenda at the insistence of a number of both developing and developed countries who believe that some large developed countries like the United States are improperly using the antidumping (AD) provisions for simple protectionist purposes. The United States agreed to the inclusions of these topics in the agenda only after proponents of reforming the $\mathrm{AD}$ and countervailing-duty (CVD) provisions agreed to add the phrase "while preserving the basic concepts, principles and effectiveness of these Agreements and their instruments and objectives.”

Countries seeking to prevent the use of the AD rules for protectionist purposes have made such proposals as: (1) no longer allowing the so-called 'zeroing” practice of calculating dumping margins without including transactions where the prices charged by foreign producers were above (rather than below) the producer's home price and (2) limiting the use in investigations only of the "facts" supplied by the domestic producers bringing the AD charges in calculating $\mathrm{AD}$ margins. In contrast, U.S. negotiators have proposed rule changes making it easier to impose AD and CVDs. For example, they have proposed rule changes that would: (1) allow members to cumulate both dumped imports and subsidized imports in order to assess the overall effects of unfair imports on the domestic industry and (2) would weaken the requirement that investigating authorities separate and distinguish the injurious effects of different causal factors. 
The Cancun meeting collapsed before any serious negotiations on the dumping and countervailing duty rules. But the bargaining positions of the two sides seem so far apart that there seems little chance of reaching agreement within the foreseeable future. What may be needed before negotiations succeed is, as suggested by some trade specialists (see Lindsay and Ikenson 2002), for WTO members to focus first on defining the basic concepts, principles, and objectives of the Antidumping Agreement. During this time, the rapid increase that is occurring in the number of dumping actions brought against the United States by developing and small developed countries for what seems to be outright protectionist purposes also may convince U.S. negotiators that basic reform of the Agreement is needed.

\section{f. Market Access for Non-Agricultural Products}

A negotiating area within which it has usually been possible to achieve a satisfactory balance of concessions for all members separately from the outcome of negotiation in other areas is market access for non-agricultural products protected by tariffs. Governments recognize that some domestic groups may face difficult adjustment problems but believe that the more efficient use of the country's resources produces a net overall economic gain. Consequently, seeking agreement on the tariff-cutting rules would seem to be a priority area for serious negotiations prior to agreeing on negotiating modalities in the some of the areas where there is still much disagreement among members. The drafts of the Cancun Ministerial prepared by the chair of the General Council, the Director-General of the WTO, and the chair of meetings in Cancun all call for employing a non-linear tariff-cutting formula that is applied on a line-by-line basis "which shall take fully into account the special needs and interests of developing and least-developed country participants, including through less than full reciprocity in reduction commitments.” This is the type of formula that was followed in the Uruguay Round. Although some countries, e.g., India, have expressed a preference for a linear tariff-cutting formula, they have not rejected the nonlinear approach outright. 


\section{g. Services}

As with regard to most agenda items, the offers to liberalize trade in services have thus far been modest. The United States and Japan, for example, have merely offered to bind concessions they had made in the Uruguay Round. However, the EU has expressed willingness to a further opening of such sectors as telecommunications, insurance, banking, tourism, and distribution. Among developing countries, India has offered to open a number of services sectors including financial services, construction and engineering, health, accounting, and tourism. In return, it is seeking greater movement of professionals in developed countries and the complete of business process outsourcing. China's initial offer lifts the requirement that foreign providers of software implementation services partner with a Chinese firm but also places new restrictions on foreign ownership of retail outlets. Offers from most other developing countries have been negligible, but it has been reported that the United States and EU are only seeking limited or no new services commitments from these countries. (ITR, Sept. 11, 2004, p. 1498). Thus, judging by the initial offers, it would seem that Doha Round negotiations in the services sector will consist more of consolidating the accomplishment in the Uruguay Round than opening important new services areas.

\section{h. Other Agenda Issues}

There are a number of other important items on which WTO members have agreed to negotiate in the Doha Round and where agreement will be difficult to reach. For example, in the area of intellectual property rights the participants have agreed to negotiate on "the establishment of a multilateral system of notification and registration of geographical indications for wines and spirits” and various countries are pressing for the extension of such a system to include a number of other agricultural products. Efforts "to clarify and improve WTO disciplines on fisheries subsidies” will be another difficult topic of negotiation. Still other subjects on which members have agreed to improve and clarify procedures but on which there are widely divergent views 
include the dispute settlement process, WTO provisions applying to regional agreements, and trade and the environment.

\section{IS A BALANCED OUTCOME POSSIBLE WITH A MORE LIMITED AGENDA?}

There seems little doubt but that governments very much want the Doha Round negotiations to succeed in the sense of achieving a favorable outcome for their countries. Most government leaders recognize the important role ongoing negotiations play in restraining protectionist pressures by both domestic groups and preventing foreign countries from introducing protectionist measures. However, in view of the reduced number of items on which negotiations now seem feasible because of the significant negotiating differences on a number of subjects set forth in the Doha Round Declaration, a key question is whether a balance of concessions and gains is possible for WTO members under a more limited negotiating agenda.

\section{a. The Developing Countries}

Obviously one of the key groups determining whether such a balance is possible is the developing countries, particularly the Group of 20 who refused to accept the negotiating positions of the developed countries at Cancun. As noted earlier, one difficulty of reaching a bargaining equilibrium when a new group emerges with veto power in a negotiation is that it is likely to take some time for its members to agree among themselves on their minimally acceptable negotiating position. There are bound to be differences in negotiating positions within the group, and determining the relative power of the members in agreeing on the various other issues besides agriculture and the Singapore issues is likely to prove difficult. However, a favorable feature for the other negotiating participants is that the solution to the collective-good problem facing the developing countries is likely to be more satisfactory. A group of countries working together is more likely to arrive at a negotiating position that benefits both themselves and the rest of the 
world more than if one or two of the countries acting individually can block a negotiating agreement.

For the developing countries as a whole, it seem clear that they will gain compared to the status quo as long as: (1) most of their implementation concerns about the Uruguay Round agreements are satisfied, (2) meaningful opening of markets for their agricultural products takes place in such developed countries such as the EU, the United States and Japan, and (3) they are not faced with the disruptive domestic adjustments likely to be associated with new WTO rules covering such Singapore issues as competition policy, government procurement and investment. However, the developed countries are likely to require some liberalization in the manufacturing and services sector of the developing countries in return for their liberalization in the agricultural sector. The most serious problem faced in negotiating a beneficial agreement with the developing countries may be the possibility that these countries will insist on making no trade concessions on grounds of fairness.

\section{The European Union}

The EU may also be one of the groups with whom it is most difficult to negotiate a balanced package of concessions and gains. Fixing a date for the phase-out of the EU's export subsidies on agricultural products is considered by a large number of both developed and developing countries to be essential for a successful Doha Round. The EU has expressed a willingness to end export subsidies on agricultural products of export interest to developing countries and has implied that agreeing to a date for the elimination of all export subsidies is not out of the question provided the United States and other agricultural exporters agree to reduce their domestic subsidy programs and modify other policies that tend to depress world prices, e.g., food aid.

At the Cancun meetings, the EU seemed to link any significant concessions on their part in the agricultural sector to an agreement to begin negotiations on the four Singapore issues. When the developing countries refused to negotiate on these subjects, EU negotiators expressed a 
willingness to postpone consideration of the investment and competition issues, but it was not clear whether the developing countries were willing to negotiate on government procurement policy and trade facilitation. As pointed out earlier, it now appears that negotiations will take place only on trade facilitation. Hopefully, the prospects that the tariff-cutting formula agreed on with regard to non-agricultural imports of developed countries will reduce higher duties by a greater percentage than lower duties (a position the EU strongly favors) and that European wines and spirits will gain geographical protection will be sufficient to persuade the EU to accept this compromise.

\section{c. The United States and Other Developed Countries}

An agreement to phase out agricultural export subsidies by a fixed date should go a long way in obtaining the support of such developed-country agricultural exporters as the United States, Canada and Australia for an overall Doha Round agreement. Including agreements to reduce tariffs on high-tech manufactured goods substantially would also increase the support of such industrial countries as the United States and Japan for reaching a successful outcome to the negotiations.

One serious threat to the overall success of the Round is a shift in the U.S. negotiating position on labor standards. Thus far, the United States has accepted the Doha ministerial decision not to negotiate multilaterally within the WTO on labor standards. It is possible, however, that U.S. negotiators may begin to insist on including enforceable labor standards as part of any Doha Round agreement. If this occurs, it seems quite likely that a number of developing countries will choose to withdraw from the negotiations rather than accept what they consider to be an unacceptable form of protectionism.

\section{d. Summary and Considerations}

A set of agreements covering a more limited agenda than outlined in the Doha Ministerial Declaration yet achieving a balance of gains and concessions for all participants does seem 
feasible. The Work Program outline in this Declaration turned out to be more a wish-list compendium rather than a realistic negotiating agenda. But it will be difficult to achieve a balance between reciprocity and fairness. It requires important change in the scope of the negotiations and in the manner in which the participants conduct the negotiations. All the participants must recognize that several items on the agenda require much more study concerning the economic, political and social implications of establishing new WTO rules pertaining to the matters they cover before serious negotiations are possible. The major developed-country trading powers must recognize that the new bargaining power of the developing countries means that the negotiating goals of the developing countries must be given much more consideration if the negotiations can achieve a successful conclusion. At the same time, the developing countries must appreciate that a successful negotiation is not possible by simply applying concepts of "fairness" to establish new rules. They must appreciate more fully the political reality that they too must be willing to undertake liberalizing actions. Finally, WTO members must recognize that the use of bilateral and regional trade agreements simply as a way of avoiding the need to make difficult compromises with other trading partners is likely over the long term to undermine the role of trade agreements as a means of promoting stability and prosperity in the world trading system. 


\section{REFERENCES}

Baldwin, R. E. (1965), 'Tariff-Cutting Techniques in the Kennedy Round,' in R. E. Baldwin et al, Trade, Growth, and the Balance of Payments: Essays in Honor of Gottfried Haberler. (Chicago: Rand McNally and Company).

Bureau of National Affairs (2004), International Trade Reporter (Washington, D.C.)

Catudal, H. M. (1958), 'How a Trade Agreement is Made,' reprinted from Department of State Bulletin (February 14), Revised, U.S. Department of State.

Dielbold, Jr., W. (1952), The End of the I.T.O., Essays in International Finance, No.16, (International Finance Section, Princeton University).

Lindsey, B. and D. Ikenson (2002), 'Reforming the Antidumping Agreement: A Road Map for WTO Negotiations,' Trade Policy Analysis, no. 21 (Washington, D.C. Cato Institute).

Preeg, E. H. (1970), Traders and Diplomats: An Analysis of the Kennedy Round of Negotiations under the General Agreement on Tariffs and Trade (Washington, D.C., The Brookings Institution).

Preeg, E. H. (1995), Traders in a Brave New World: The Uruguay Round and the Future of the International Trading System (Chicago: The University of Chicago Press).

World Trade Organization (2001), Draft Ministerial Declaration, WT/MIN(01)/DEC/W/1 (November 14).

Winham, G. R. (1986), International Trade and the Tokyo Round Negotiations (Princeton: Princeton University Press). 